\title{
Field Operations Program
}

\section{Neighborhood Electric Vehicle Fleet Use}

\author{
J. Francfort \\ M. Carroll \\ July 2001
}

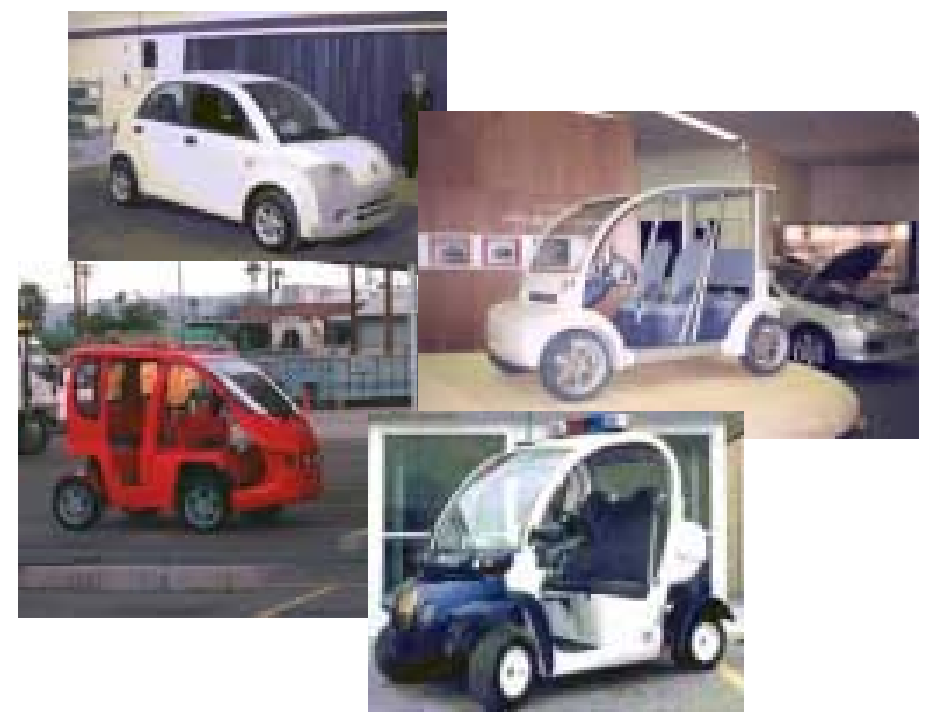

United States Department of Energy 


\title{
Field Operations Program Neighborhood Electric Vehicle Fleet Use
}

\author{
J. Francfort \\ M. Carroll
}

July 2001

Idaho National Engineering and Environmental Laboratory Transportation Technologies \& Infrastructure Department Idaho Falls, Idaho 83415 


\section{Disclaimer}

This document highlights work sponsored by agencies of the U.S. Government. Neither the U.S.

Government nor any agency thereof, nor any of their employees, makes any warranty, express or implied, or assumes any legal liability or responsibility for the accuracy, completeness, or usefulness of any information, apparatus, product, or process disclosed, or represents that its use would not infringe privately owned rights. Reference herein to any specific commercial product, process, or service by trade name, trademark, manufacturer, or otherwise does not necessarily constitute or imply its endorsement, recommendation, or favoring by the U.S. Government or any agency thereof. The views and opinions of authors expressed herein do not necessarily state or reflect those of the U.S. Government or any agency thereof. 


\section{SUMMARY}

This report summarizes a study of 15 automotive fleets that operate neighborhood electric vehicles (NEVs) in the United States. The information was obtained to help Field Operations Program personnel understand how NEVs are being used, how many miles they are being driven, and if they are being used to replace other types of fleet vehicles or as additions to fleets. (The Field Operations Program is a U.S. Department of Energy Program within the DOE Office of Energy Efficiency and Renewable Energy, Transportation Technologies).

The fifteen fleets operate a total of 348 NEVs in a variety of missions. The fleets include military, commercial, municipal, rental, and transportation organizations. The NEV fleets range in size from 2 to $82 \mathrm{NEVs}$ with an average (mean) of 23 and a median size of 10 . Thirty percent of the 348 NEVs were purchased as replacement vehicles. Fifty-six percent of the NEVs are used on private roads, $32 \%$ are used on public roads, and $12 \%$ are used on both public and private roads. The fleets reported that $91 \%$ of the $348 \mathrm{NEVs}$ did not have any problems; 14 of the NEVs have had their battery packs replaced. The fleets are charging $99 \%$ of their NEVs at 110 volts.

The NEVs' contribution to petroleum avoidance and cleaner air can be estimated based on the miles driven and by assuming gasoline use and air emissions values for the vehicles being replaced. Gasoline and emissions data for a Honda Civic are used as the Civic has the best fuel use for a gasoline-powered vehicle and very clean emissions. Based on these conservative assumptions, the $348 \mathrm{NEVs}$ are being driven a total of about 1.2 million miles per year. This equates to an average of 3,409 miles per NEV annually or 9 miles per day. It is estimated that 29,195 gallons of petroleum use is avoided annually by the 348 NEVs. This equates to 87 gallons of petroleum use avoided per NEV, per year. Using the 348 NEVs avoids the generation of at least 775 pounds of smogforming emissions annually.

Based on the comments received, the fifteen fleets have had positive experiences with their NEVs. 


\section{CONTENTS}

SUMMARY

iii

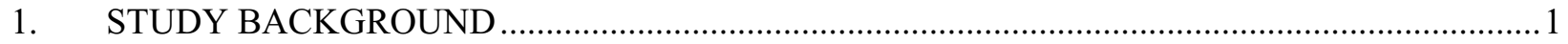

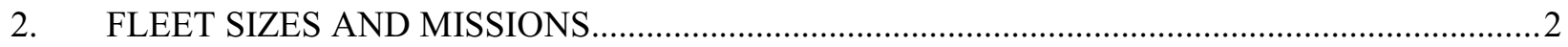

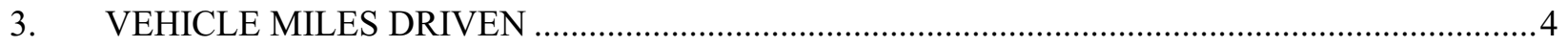

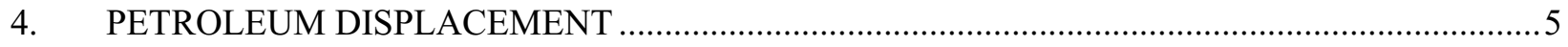

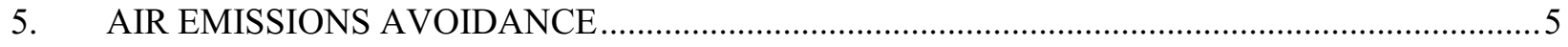

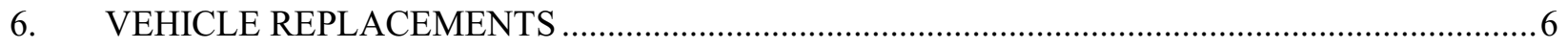

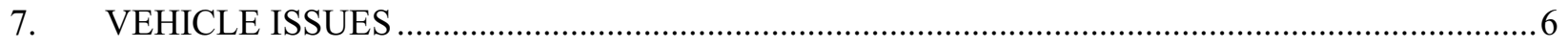

8. BATTERY PACKS AND CHARGING SYSTEMS …..........................................................

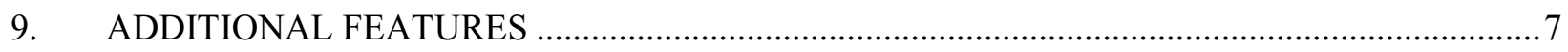

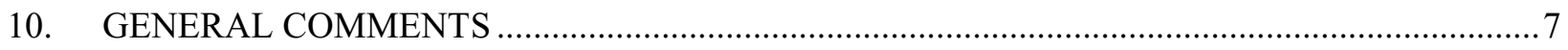

Appendix A-Individual Fleet Responses

FIGURES

Figure 1. Ford/Th!nk Neighborhood NEV ..................................................................................... 1

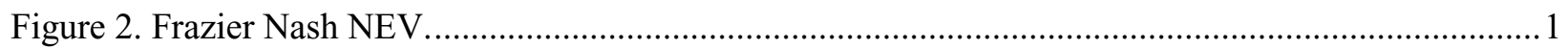

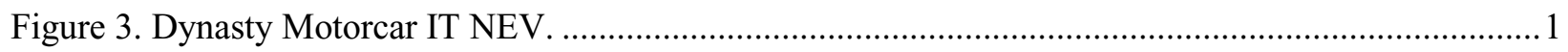

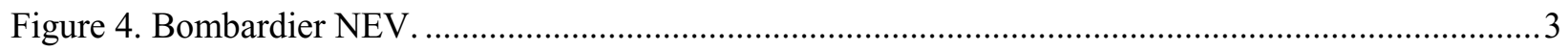

Figure 5. GEM NEVs in different applications.............................................................................

Figure 6. Average annual miles driven per NEV, for the eleven fleets reporting mileage for their 162 NEVs. The weighed average annual miles driven per NEV is 3,409 miles. 


\section{Field Operations Program Neighborhood Electric Vehicles Fleet Use}

\section{STUDY BACKGROUND}

To better understand fleet use of neighborhood electric vehicles (NEVs), the Field Operations Program conducted a study of fifteen fleets that were known to be using NEVs. Personnel from the Idaho National Engineering and Environmental Laboratory contacted the fifteen fleets by telephone and asked about 20 questions. The individual responses for the fifteen fleets are available in Appendix A and summarized on the next few pages. The study was not intended as a scientific sample, rather, as an informal analysis of NEV use and experience.

The Field Operations Program is a U.S. Department of Energy (DOE) Program (within the Office of Energy Efficiency and Renewable Energy, Transportation Technologies) that works with commercial and government fleets, and industry groups to support the testing and deployment of advanced technology vehicles in today's evolving transportation market. The program provides unbiased information about alternative fuel and advanced transportation technologies that reduce U.S. dependence on foreign oil, while improving the nation's air quality.

A NEV is 4-wheeled, generally larger than a golf cart but smaller than a light-duty passenger vehicle. NEVs are usually configured to carry two or four passengers (Figures 1,2 and 3), or two passengers with a pickup type of bed, or two passengers with various maintenance support equipment.

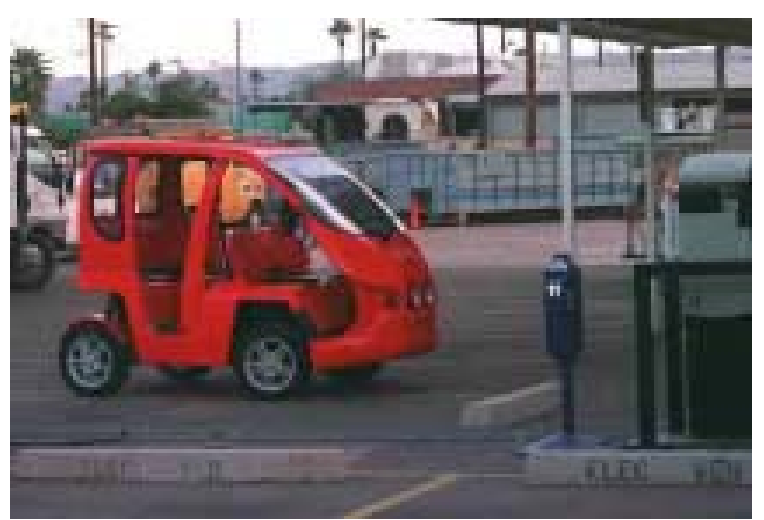

Figure 2. Frazier Nash NEV.

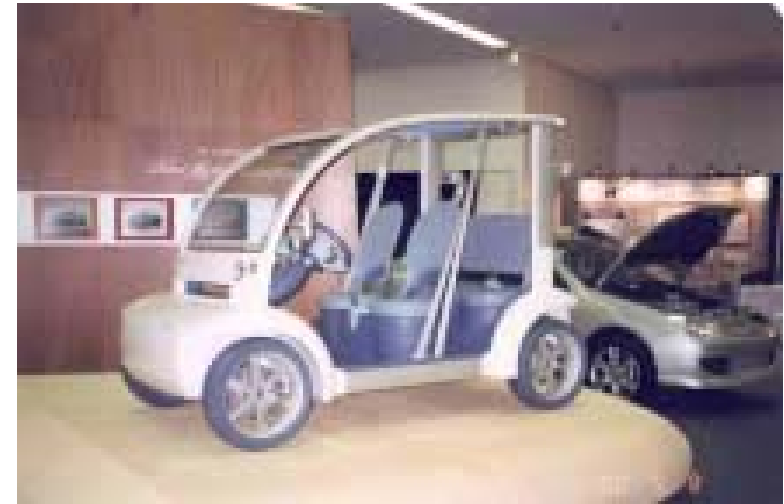

Figure 1. Ford/Th!nk Neighborhood NEV.

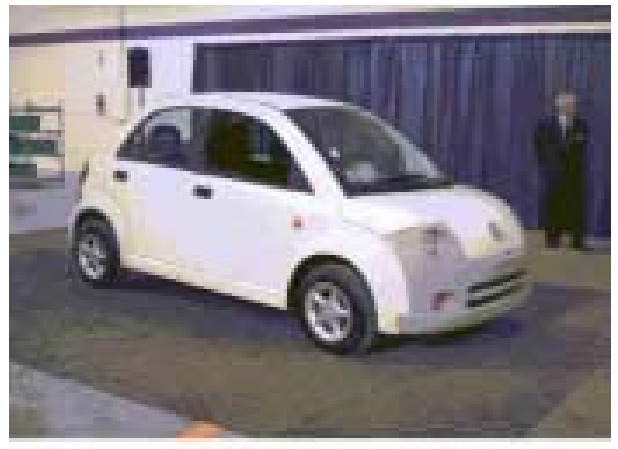

Figure 3. Dynasty Motorcar IT NEV. 
NEVs are defined by the National Highway Traffic Safety Administration as subject to Federal Motor Vehicle Safety Standard No. 500 (49 CFR 571.500). Per FMVSS 500, NEVs have top speeds between 20 and $25 \mathrm{mph}$ and are defined as "Low Speed Vehicles" (LSV). While "Low Speed Vehicle" is technically the correct term, "NEV" has become the term used by industry and fleets to refer to passenger vehicles subject to FMVSS 500.

FMVSS 500 requires that NEVs be equipped with headlamps, stop lamps, turn signal lamps, tail lamps, reflex reflectors, parking brakes, rear view mirrors, windshields, seat belts, and vehicle identification numbers. About 30 states have passed legislation or regulations allowing NEVs to be licensed and driven on roads that are generally posted at $35 \mathrm{mph}$.

While NEVs were initially used in gated communities, they have been increasingly used by the general public for neighborhood use such as transporting kids to school, shopping, and general neighborhood trips. NEVs are very cost efficient, in terms of initial capital costs, fuel costs, and overall operating expenses.

As part of its 2003 zero emissions mandates, the California Air Resource Board (CARB) approved 4 credits for NEVs used in California during the years 2001 and 2002, with decreasing credits after 2002. Many expect that NEVs will be used by original equipment automotive manufacturers to meet at least part of their zero emission mandates by 2003.

In addition to the above uses, many federal, private, and public fleets are increasingly using NEVs at military bases, national parks, and commercial airports, as well as for local government activities. NEVs are reducing petroleum use and simplifying fueling requirements by decreasing or eliminating the need for gasoline infrastructure. For federal fleets, the use of NEVs can significantly decrease petroleum use, helping the federal fleets comply with Executive Order 13149 ("Greening The Government Through Federal Fleet and Transportation Efficiency"), which requires a $20 \%$ decrease in annual petroleum use by fiscal year 2005 .

\section{FLEET SIZES AND MISSIONS}

The fifteen fleets have 348 NEVs. The NEV fleet sizes ranged from 2 to 82 NEVs. The average (mean) number of NEVs per fleet is 23 and the median number is $10 \mathrm{NEVs}$ per fleet. For the 10 fleets that also reported the total number of all 4 -wheeled passenger/pickup/utility vehicles, their average fleet size was 291 vehicles, and on average the NEVs comprised $6 \%$ of their total fleets.

The models of NEVs used by the fleets includes 306 Global Electric Motor Cars (GEMs) in ten fleets, 27 Bombardiers in three fleets, 4 Nissan Hyperminis in one fleet, and 11 NEVs of unknown manufacturers in two fleets. Included in this total was one fleet with a mix of 69 GEM and 13 Bombardiers (Figure 4).

The length of time the fifteen fleets have had their NEVs ranged from 1 month to 4 years, and the average time of possession is 1 year and 4 months. Three fleets stated they were ordering 18 additional NEVs and five more fleets reported they might order additional NEVs in the future. 


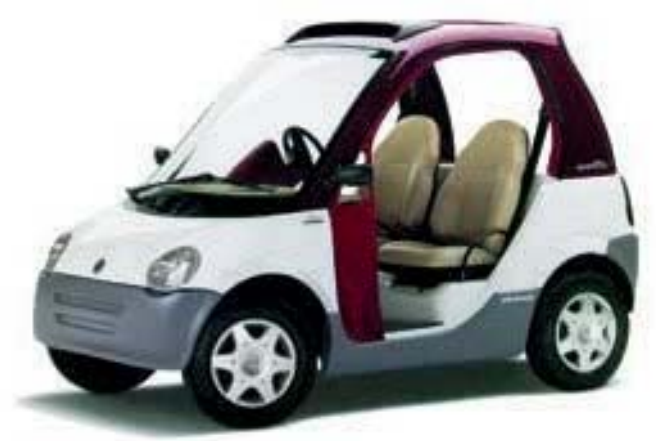

Figure 4. Bombardier NEV.

The NEVs are being used in a variety of applications (Figure 5), with $56 \%$ used on private roads, $32 \%$ used on public roads and $12 \%$ used on both public and private. Below is a list of the missions and locations for the NEVs. The fleets identified the following:

- $\quad$ Ground support at two airports

- $\quad$ Two military bases

- $\quad$ Administrative purposes

- Delivery capacity

- $\quad$ Rental vehicles -2 fleets

- $\quad$ General city business

- $\quad$ Parks \& recreation

- $\quad$ Employee transportation -2 fleets

- $\quad$ Maintenance support -2 fleets

- $\quad$ National Park

- $\quad$ Placing NEVs in low income family neighborhoods to replace run-down gasoline vehicles

- $\quad$ Allowing people to try them out in neighborhoods and a park

- Water meter reading

- School campus patrol

- $\quad$ Police departments

- Neighborhood patrol

- General company errands. 


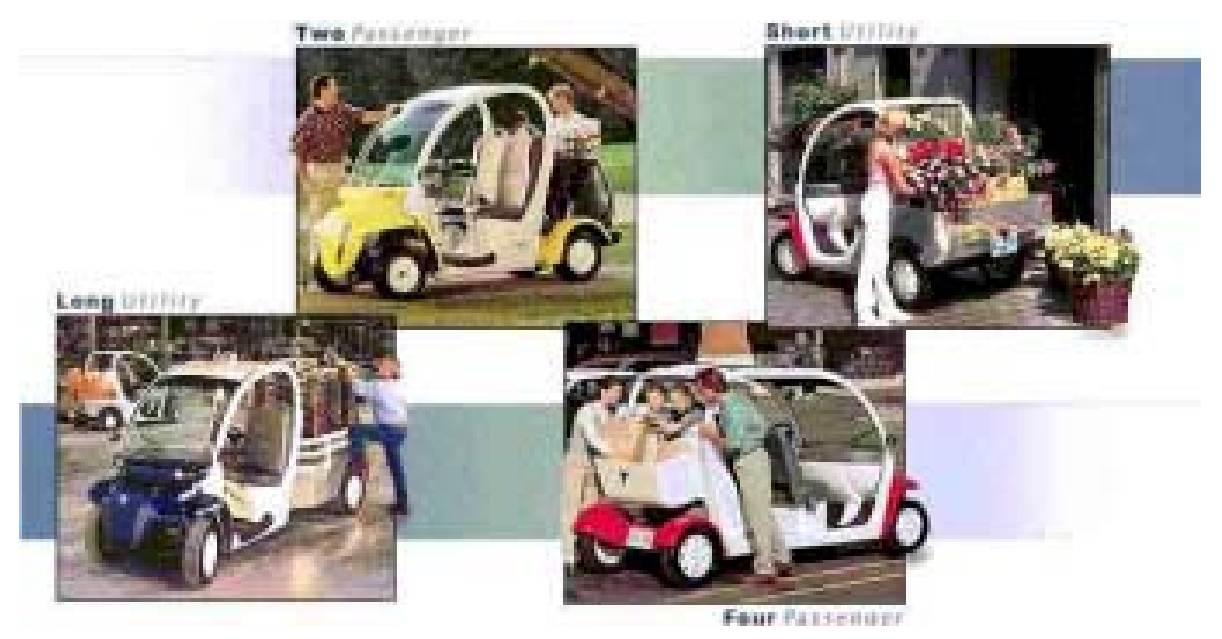

Figure 5. GEM NEVs in different applications.

\section{VEHICLE MILES DRIVEN}

Eleven of the fifteen fleets were able to report the number of miles the NEVs are being driven on either a daily, weekly, or monthly basis. The 162 NEVs operated by these eleven fleets are being driven a total of 552,302 miles per year, averaging 3,409 miles per NEV annually. The average annual miles driven per NEV ranged from 416 miles to 13,000 miles (Figure 6). Assuming a five-day workweek, the average miles driven per day is 13 miles. Many of the 162 NEVs are driven 7 days per week, so based on 3,409 miles per year, the NEVs average 9 miles per day.

If the average annual number of miles $(3,409)$ driven per NEV is extrapolated to the $348 \mathrm{NEVs}$ in the 15 fleets, the total number of miles driven by the $348 \mathrm{NEVs}$ is 1.2 million emission-free miles per year.

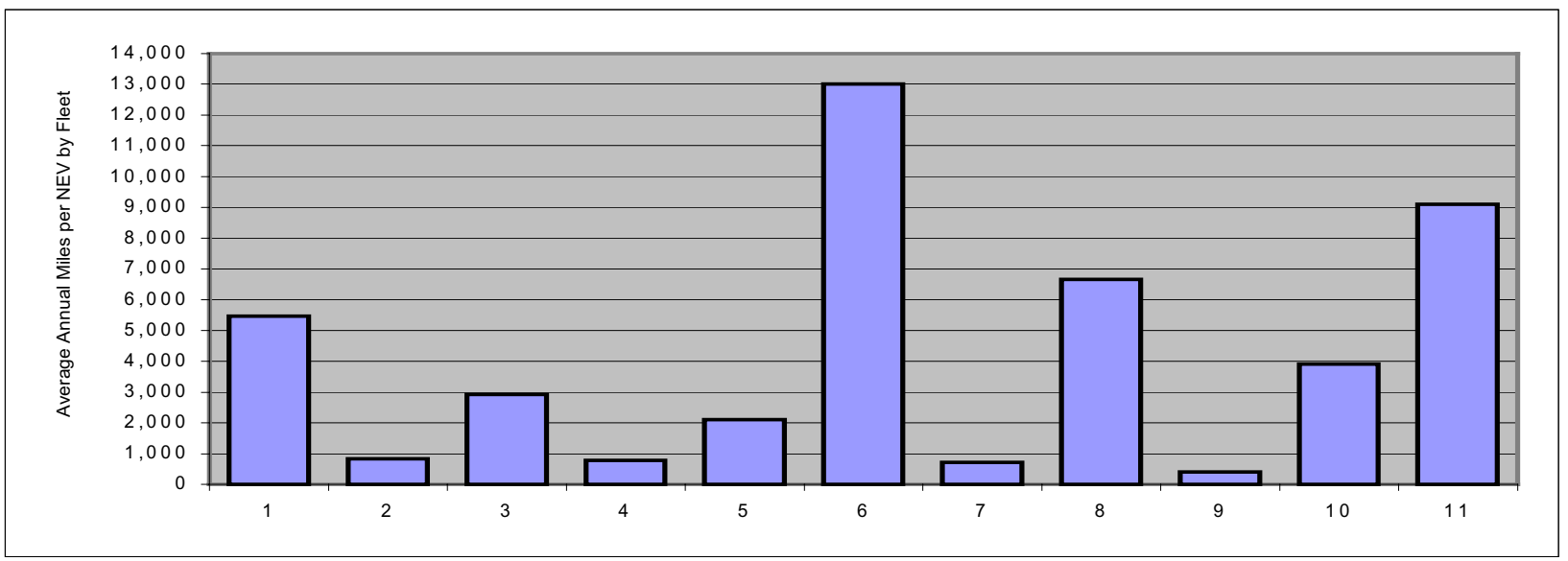

Figure 6. Average annual miles driven per NEV, for the eleven fleets reporting mileage for their 162 NEVs. The weighed average annual miles driven per NEV is 3,409 miles. 


\section{PETROLEUM DISPLACEMENT}

When the Field Operations Program designed and tested the study questions, it requested petroleum displacement information but quickly discovered that the fleets had not collected it. In the attempt to estimate petroleum displacement, the following assumptions are employed.

Of the 105 NEVs purchased to replace another vehicle in the fleets, at least 91 (87\%) of the 105 replaced vehicles were petroleum powered (see Vehicle Replacements section below).

For the vehicles replaced by the NEVs, it is not known what their fuel efficiency was, so 39 miles per gallon (mpg) will be assumed. The EPA Fuel Economy Guide for Model Year 2000 lists 39 mph for the Honda Civic (http://www.fueleconomy.gov/feg/FEG2000.htm), which is the highest mileage of all gasoline vehicles. While some of the gasoline golf carts may be capable of better mileage, the start-stop duty cycle of these vehicles will result in poor mpg. The mileage for the full-size gasoline vehicles would be considerably lower than the 39-mpg assumption.

Since $87 \%$ of the replacement vehicles are gasoline powered, it is assumed that the $91 \mathrm{NEVs}$ are driven 310,219 petroleum-free miles per year $(3,409 \times 91)$.

It is assumed that if the remaining 243 new NEVs (not replacement NEVs) were not purchased, then vehicles powered by petroleum would have been purchased instead. Therefore, the $243 \mathrm{NEVs}$ are driven 828,387 petroleum-free miles per year $(3,409$ x 243$)$.

Given the above assumptions, the 348 NEVs represent an additional 1,138,606 $(828,387+$ $310,219)$ petroleum-free miles annually. It is also estimated that 29,195 gallons $(1,138,606 / 39)$ of petroleum is avoided annually by the 348 NEVs. This equates to 87 gallons $(3,409$ / 39) of petroleum avoided per NEV per year.

The above mileage analysis employs fairly conservative assumptions (including the $39 \mathrm{mpg}$ average), but it is known that 16 of the NEVs replaced full-size gasoline vehicles. In fact, three NEVs have been used by AMFAC to replace 1/2-ton Ford pickup trucks in Yellowstone National Park. If the average Ford F150 pickup mileage of 18 mpg is used (EPA Fuel Economy Guide for Model Year 2000), each of the Yellowstone NEVs avoids using at least 189 gallons $(3,409$ / 18) of petroleum annually.

\section{AIR EMISSIONS AVOIDANCE}

Definitively determining the air pollution benefits of the 348 NEVs is even more difficult than determining the petroleum displacement benefits. Generally, the replaced vehicles did not have catalytic converters, nor is it likely that the majority were ever required to have any type of emission equipment, so the use of NEVs has a positive impact on air emissions.

The same Honda Civic will be used to estimate the pounds of smog forming pollution avoided by using the NEVs. Per the EPA Green Vehicle Guide (http://www.epa.gov/autoemissions/), the Emission Air Pollution Score for the Honda Civic is "7". A "7" equates to 7.9 to 11.8 pounds of smog forming pollution every 15,000 miles. Using 9.8 pounds per 15,000 miles as the average, the $1,186,332$ annual miles driven by the 348 NEVs avoids 775 pounds of smog-forming emissions annually $(1,186,332$ / $15,000 \times 9.8$ ). On a per NEV basis, the 3,409 miles driven annually avoids about 2 pounds of smogforming emissions annually $(3,409 / 15,000 \times 9.8)$.

The above air emissions avoidance analysis also employs fairly conservative assumptions (including the 9.8 pounds of smog forming pollution every 15,000 miles). By again using the example of 
the three NEVs used by AMFAC to replace the 1/2 ton Ford pickup trucks in Yellowstone National Park, another analysis can be performed to estimate the upper limit of emissions benefits. Per the EPA Green Vehicle Guide, the Emission Air Pollution Score for a F150 pickup is a " 3 ". The " 3 " equates to 27.4 to 36.3 pounds of smog forming pollution every 15,000 miles. Using 31.9 pounds per 15,000 miles as the average and the 3,409 miles driven annually, each NEV can avoid as much as 7 pounds of annual smogforming emissions $(3,409 / 15,000 \times 31.9)$.

\section{VEHICLE REPLACEMENTS}

The fleets were asked how many of the NEVs were replacing a fleet vehicle and what type of vehicle was replaced; 105 (30\%) of the $348 \mathrm{NEVs}$ were purchased as replacement vehicles. Either gasoline or diesel engines powered at least 91 of the 105 vehicles replaced. The number and types of vehicles replaced by the NEVs are listed below.

- $\quad 13$ full-size gasoline vehicles

- $\quad 3$ gasoline 1/2-ton gas pickups

- $\quad 2$ Daihatsu gasoline pickups

- 5 gas golf cars

- 1 diesel golf car

- $\quad 32$ gasoline golf and industrial carts

- $\quad 35$ gasoline scooters

- 10 golf cars (unsure if gasoline or electric)

- 4 three-wheel electric parking meter vehicles.

\section{VEHICLE ISSUES}

Of the 348 NEVs, approximately 91\% have not had any problems. Of the 30 NEVs with problems, 14 had battery pack problems (see next section). The other 16 problems were varied and they included:

- $\quad 2$ - chargers replaced

- $\quad 2$ - controller boxes

- $\quad 2$ - transmissions

- $\quad 4$ - controller failures

- $\quad 5$ - malfunction switches

- 1 - front suspension. 


\section{BATTERY PACKS AND CHARGING SYSTEMS}

Of the 348 NEVs purchased, fourteen had their lead-acid battery packs replaced. Seven of the packs were replaced within the first year, under warranty. One of the fleets acknowledged not watching the water level on their $12 \mathrm{NEVs}$ and they replaced the original flooded lead-acid battery packs with gel cell lead-acid batteries.

All of the NEVs have onboard chargers, with 344 using 110-volt plugs. Four NEVs in one fleet are being charged at 220 volts. One fleet indicated that it was using both fast charging and 110 volt charging for one of its NEVs. However, most of the fleets expressed interest in fast charging, with one fleet planning on fast charging 10 of their NEVs in the near future.

\section{ADDITIONAL FEATURES}

Several of the fleets indicated some specific features that they would like to see on NEVs, while four of the fleets said that they would not change anything about their NEVs. The additional features mentioned as desirable were:

- $\quad$ Canvas doors

- $\quad$ Permanent doors -7 fleets mentioned this

- $\quad$ Hooks for towing

- $\quad$ Storage bins

- $\quad$ The ability to carry more passengers

- $\quad$ Top speeds of $40-45 \mathrm{mph}$

- Windows that roll down

- $\quad$ Longer ranges.

\section{GENERAL COMMENTS}

The fleets were asked for any general comments that they had about their NEVs. The comments were generally very positive. The comments included:

- Happy with the NEVs so far - 2 fleets

- The vehicles are very capable

- $\quad$ Drivers are very tough to make the paradigm shift to NEVs

- $\quad$ Very capable vehicles

- $\quad$ Great, work well, very happy

- The right tool for the right job 
- They work better than the gasoline utility vehicles they replaced

- $\quad$ Great little vehicle

- 6-volt batteries hold up better than 8- or 12-volt batteries

- $\quad$ Seem to be noisy, possibly caused by the canvas doors

- $\quad$ Everything is made of plastic and deteriorates quickly. 
Appendix A

\section{Individual Fleet Responses}




\section{Appendix A \\ Individual Fleet Responses}

\begin{tabular}{|c|c|}
\hline \multicolumn{2}{|l|}{ Agency/Department/Company: America West Airlines } \\
\hline \multicolumn{2}{|l|}{ Location: Phoenix, AZ } \\
\hline $\begin{array}{l}\text { How may } 4 \text {-wheeled passenger/pickup/utility vehicles are in } \\
\text { your fleet (including NEVs)? }\end{array}$ & 1,186 \\
\hline How many NEVs are in your fleet? & 62 GEMs \\
\hline What are the NEVs generally used for? & Multipurpose \\
\hline How long have you had NEVs in your fleet? & $6-9$ months \\
\hline Do you have any more NEVs on order (if yes, please specify)? & No \\
\hline Have you had any problems with the NEVs? & No \\
\hline $\begin{array}{l}\text { How many miles are your NEVs driven on average } \\
\text { Per NEV? } \\
\text { Per NEV Fleet? }\end{array}$ & UNKNOWN \\
\hline How many NEVs were replacement vehicles? & 10 \\
\hline $\begin{array}{l}\text { If replacement vehicles, list how many and what types of } \\
\text { vehicles the NEVs replaced: }\end{array}$ & 7 Gasoline, 3 Golf Carts \\
\hline $\begin{array}{l}\text { Are your NEVs used on public roads, private roads/base, or } \\
\text { both? }\end{array}$ & Airport only \\
\hline $\begin{array}{l}\text { Are there any additional features you would like your NEVs to } \\
\text { have: }\end{array}$ & None \\
\hline Are you using 110 or $220 \mathrm{~V}$ charging? & 110 \\
\hline Are you using fast charging for your NEVs? & Yes \\
\hline If yes, how many NEVs are being fast charged? & 1 right now \\
\hline Have you had to replace any NEV battery packs? & No \\
\hline $\begin{array}{l}\text { If yes, what was the average pack cost or were they under } \\
\text { warranty? }\end{array}$ & \\
\hline $\begin{array}{l}\text { If yes, what were the average miles on the replaced battery } \\
\operatorname{pack}(\mathrm{s}) ?\end{array}$ & \\
\hline Please provide any additional comments you have: & \\
\hline
\end{tabular}




\begin{tabular}{|c|c|}
\hline \multicolumn{2}{|c|}{ Agency/Department/Company: AMFAC (Yellowstone National Park Concessionaire) } \\
\hline \multicolumn{2}{|l|}{ Location: Mammoth, WY } \\
\hline \multicolumn{2}{|l|}{$\begin{array}{l}\text { How may } 4 \text {-wheeled passenger/pickup/utility vehicles are in } \\
\text { your fleet (including NEVs)? }\end{array}$} \\
\hline How many NEVs are in your fleet? & 3 \\
\hline What are the NEVs generally used for? & Maintenance \\
\hline How long have you had NEVs in your fleet? & Mid-April, 2000 \\
\hline Do you have any more NEVs on order (if yes, please specify)? & 3 \\
\hline Have you had any problems with the NEVs? & No \\
\hline $\begin{array}{l}\text { How many miles are your NEVs driven on average } \\
\text { Per NEV? } \\
\text { Per NEV Fleet? }\end{array}$ & 50 miles/day/NEV \\
\hline How many NEVs were replacement vehicles? & 3 \\
\hline $\begin{array}{l}\text { If replacement vehicles, list how many and what types of } \\
\text { vehicles the NEVs replaced: }\end{array}$ & Gasoline Ford $1 / 2$ ton trucks \\
\hline $\begin{array}{l}\text { Are your NEVs used on public roads, private roads/base, or } \\
\text { both? }\end{array}$ & Both \\
\hline $\begin{array}{l}\text { Are there any additional features you would like your NEVs to } \\
\text { have: }\end{array}$ & None \\
\hline Are you using 110 or $220 \mathrm{~V}$ charging? & 110 \\
\hline \multicolumn{2}{|l|}{$\begin{array}{l}\text { Are you using fast charging for your NEVs? } \\
\text { If yes, how many NEVs are being fast charged? }\end{array}$} \\
\hline Have you had to replace any NEV battery packs? & No \\
\hline \multicolumn{2}{|l|}{$\begin{array}{l}\text { If yes, what was the average pack cost or were they under } \\
\text { warranty? }\end{array}$} \\
\hline \multicolumn{2}{|l|}{$\begin{array}{l}\text { If yes, what were the average miles on the replaced battery } \\
\operatorname{pack}(\mathrm{s}) \text { ? }\end{array}$} \\
\hline \multicolumn{2}{|l|}{ Please provide any additional comments you have: } \\
\hline They work better than the gasoline utility vehicles we have us & pefore. \\
\hline
\end{tabular}




\begin{tabular}{|c|c|}
\hline \multicolumn{2}{|l|}{ Agency/Department/Company: Anaheim Transportation Network } \\
\hline \multicolumn{2}{|l|}{ Location: Anaheim, CA } \\
\hline $\begin{array}{l}\text { How may 4-wheeled passenger/pickup/utility vehicles are in } \\
\text { your fleet (including NEVs)? }\end{array}$ & $?$ \\
\hline How many NEVs are in your fleet? & 10 GEMs \\
\hline What are the NEVs generally used for? & Transportation (see comments below \\
\hline How long have you had NEVs in your fleet? & Jan 2001 \\
\hline Do you have any more NEVs on order (if yes, please specify)? & No \\
\hline Have you had any problems with the NEVs? & 1 charger replaced \\
\hline $\begin{array}{l}\text { How many miles are your NEVs driven on average } \\
\text { Per NEV? } \\
\text { Per NEV Fleet? }\end{array}$ & $\begin{array}{l}1 \text { is currently being driven } 4 \text { miles a } \\
\text { day }\end{array}$ \\
\hline How many NEVs were replacement vehicles? & 0 \\
\hline \multicolumn{2}{|l|}{$\begin{array}{l}\text { If replacement vehicles, list how many and what types of } \\
\text { vehicles the NEVs replaced: }\end{array}$} \\
\hline $\begin{array}{l}\text { Are your NEVs used on public roads, private roads/base, or } \\
\text { both? }\end{array}$ & Public \\
\hline $\begin{array}{l}\text { Are there any additional features you would like your NEVs to } \\
\text { have: }\end{array}$ & Permanent doors \\
\hline Are you using 110 or $220 \mathrm{~V}$ charging? & 110 \\
\hline $\begin{array}{l}\text { Are you using fast charging for your NEVs? } \\
\text { If yes, how many NEVs are being fast charged? }\end{array}$ & No \\
\hline Have you had to replace any NEV battery packs? & No \\
\hline \multicolumn{2}{|l|}{$\begin{array}{l}\text { If yes, what was the average pack cost or were they under } \\
\text { warranty? }\end{array}$} \\
\hline \multicolumn{2}{|l|}{$\begin{array}{l}\text { If yes, what were the average miles on the replaced battery } \\
\operatorname{pack}(\mathrm{s}) \text { ? }\end{array}$} \\
\hline \multicolumn{2}{|l|}{ Please provide any additional comments you have: } \\
\hline \multicolumn{2}{|c|}{$\begin{array}{l}\text { We are a non-profit organization, placing NEVs in low-income family neighborhoods to replace gas } \\
\text { run-down vehicles for multiple families. We report to the California Energy Commission (miles, places } \\
\text { driven to, times checked in and out. Seem to be noisy, they have canvas doors, possibly causing the } \\
\text { rattling. }\end{array}$} \\
\hline
\end{tabular}




\begin{tabular}{|c|c|}
\hline \multicolumn{2}{|l|}{ Agency/Department/Company: City of Palm Springs } \\
\hline \multicolumn{2}{|l|}{ Location: Palm Springs, CA } \\
\hline $\begin{array}{l}\text { How may 4-wheeled passenger/pickup/utility vehicles are in } \\
\text { your fleet (including NEVs)? }\end{array}$ & 227 \\
\hline How many NEVs are in your fleet? & 8 \\
\hline What are the NEVs generally used for? & $\begin{array}{l}\text { City Business - Police, Airport, City } \\
\text { Hall, Parks \& Rec., Fleet Op. }\end{array}$ \\
\hline How long have you had NEVs in your fleet? & 1 week \\
\hline Do you have any more NEVs on order (if yes, please specify)? & 13 (see comments below) \\
\hline Have you had any problems with the NEVs? & Not yet \\
\hline $\begin{array}{l}\text { How many miles are your NEVs driven on average } \\
\text { Per NEV? } \\
\text { Per NEV Fleet? }\end{array}$ & $\begin{array}{l}50 \mathrm{miles} / \text { week/NEV } \\
26,000 \mathrm{miles} / \mathrm{year} \text { (NEV fleet) }\end{array}$ \\
\hline How many NEVs were replacement vehicles? & 8 \\
\hline $\begin{array}{l}\text { If replacement vehicles, list how many and what types of } \\
\text { vehicles the NEVs replaced: }\end{array}$ & $\begin{array}{l}2 \text { Daihatsu Trucks, } 6 \text { larger gas } \\
\text { vehicles }\end{array}$ \\
\hline $\begin{array}{l}\text { Are your NEVs used on public roads, private roads/base, or } \\
\text { both? }\end{array}$ & Both \\
\hline $\begin{array}{l}\text { Are there any additional features you would like your NEVs to } \\
\text { have: }\end{array}$ & $\begin{array}{l}\text { Higher speed, longer range, faster } \\
\text { charging, permanent doors }\end{array}$ \\
\hline Are you using 110 or $220 \mathrm{~V}$ charging? & 110 \\
\hline $\begin{array}{l}\text { Are you using fast charging for your NEVs? } \\
\text { If yes, how many NEVs are being fast charged? }\end{array}$ & $\begin{array}{l}\text { No, but will be fast charging } 10 \\
\text { NEVs in the future. }\end{array}$ \\
\hline Have you had to replace any NEV battery packs? & No \\
\hline $\begin{array}{l}\text { If yes, what was the average pack cost or were they under } \\
\text { warranty? }\end{array}$ & \\
\hline $\begin{array}{l}\text { If yes, what were the average miles on the replaced battery } \\
\operatorname{pack}(\mathrm{s}) \text { ? }\end{array}$ & \\
\hline \multicolumn{2}{|c|}{$\begin{array}{l}\text { Please provide any additional comments you have: } \\
\text { We are lead agency to provide twenty-one NEVs to the Palm Springs \& Community via a California } \\
\text { Energy Commission Grant ( } \$ 85,000 \text { for } 21 \mathrm{NEVs}) \text {. An initial } 10 \text { NEVs }(8 \text { for city and } 2 \text { for local } \\
\text { Indian Tribe) were delivered on } 3 / 30 / 01 \text {. The remaining } 11 \text { NEVs will be placed as follows: } 2 \text { more for } \\
\text { City fleet and } 9 \text { more for Palm Springs School District and other local grant partners. The City of Palm } \\
\text { Springs currently has approval for the largest NEV fleet in California. The CEC Grant ( } \$ 85,000 \text { for } 21 \\
\text { NEVs) is } 1 \text { of } 4 \text { such CEC grants in California }-2 \text { in Southern California and } 2 \text { in Northern California. }\end{array}$} \\
\hline
\end{tabular}




\begin{tabular}{|c|c|}
\hline Agency/Department/Company: City of Santa Rosa & \\
\hline Location: Santa Rosa, CA & \\
\hline $\begin{array}{l}\text { How may 4-wheeled passenger/pickup/utility vehicles are in } \\
\text { your fleet (including NEVs)? }\end{array}$ & 920 \\
\hline How many NEVs are in your fleet? & 4 Nissan Hyperminis \\
\hline What are the NEVs generally used for? & Parking enforcement \\
\hline How long have you had NEVs in your fleet? & Nov 00 \\
\hline Do you have any more NEVs on order (if yes, please specify)? & No, possibly in the future \\
\hline Have you had any problems with the NEVs? & No \\
\hline $\begin{array}{l}\text { How many miles are your NEVs driven on average } \\
\text { Per NEV? } \\
\text { Per NEV Fleet? }\end{array}$ & 35 miles/day/vehicle \\
\hline How many NEVs were replacement vehicles? & 4 \\
\hline $\begin{array}{l}\text { If replacement vehicles, list how many and what types of } \\
\text { vehicles the NEVs replaced: }\end{array}$ & $\begin{array}{l}3 \text { wheel electric parking meter } \\
\text { vehicles, Gofors }\end{array}$ \\
\hline $\begin{array}{l}\text { Are your NEVs used on public roads, private roads/base, or } \\
\text { both? }\end{array}$ & Public \\
\hline $\begin{array}{l}\text { Are there any additional features you would like your NEVs to } \\
\text { have: }\end{array}$ & Cut down door \\
\hline Are you using 110 or $220 \mathrm{~V}$ charging? & 220 \\
\hline $\begin{array}{l}\text { Are you using fast charging for your NEVs? } \\
\text { If yes, how many NEVs are being fast charged? }\end{array}$ & No \\
\hline Have you had to replace any NEV battery packs? & No \\
\hline $\begin{array}{l}\text { If yes, what was the average pack cost or were they under } \\
\text { warranty? }\end{array}$ & \\
\hline $\begin{array}{l}\text { If yes, what were the average miles on the replaced battery } \\
\operatorname{pack}(\mathrm{s}) \text { ? }\end{array}$ & \\
\hline Please provide any additional comments you have: & \\
\hline Great little vehicle & \\
\hline
\end{tabular}




\begin{tabular}{|c|c|}
\hline \multicolumn{2}{|l|}{ Agency/Department/Company: City of Sebastopol } \\
\hline \multicolumn{2}{|l|}{ Location: Sebastopol, CA } \\
\hline $\begin{array}{l}\text { How may 4-wheeled passenger/pickup/utility vehicles are in } \\
\text { your fleet (including NEVs)? }\end{array}$ & 19 \\
\hline How many NEVs are in your fleet? & 3 GEMs \\
\hline What are the NEVs generally used for? & Transportation, Water meter reading \\
\hline \multicolumn{2}{|l|}{ How long have you had NEVs in your fleet? } \\
\hline Do you have any more NEVs on order (if yes, please specify)? & No \\
\hline Have you had any problems with the NEVs? & No \\
\hline $\begin{array}{l}\text { How many miles are your NEVs driven on average } \\
\text { Per NEV? } \\
\text { Per NEV Fleet? }\end{array}$ & $60 \mathrm{miles} / \mathrm{month} / \mathrm{NEV}$ \\
\hline How many NEVs were replacement vehicles? & 0 \\
\hline \multicolumn{2}{|l|}{$\begin{array}{l}\text { If replacement vehicles, list how many and what types of } \\
\text { vehicles the NEVs replaced: }\end{array}$} \\
\hline $\begin{array}{l}\text { Are your NEVs used on public roads, private roads/base, or } \\
\text { both? }\end{array}$ & Public roads \\
\hline $\begin{array}{l}\text { Are there any additional features you would like your NEVs to } \\
\text { have: }\end{array}$ & Permanent doors \\
\hline Are you using 110 or $220 \mathrm{~V}$ charging? & 110 \\
\hline $\begin{array}{l}\text { Are you using fast charging for your NEVs? } \\
\text { If yes, how many NEVs are being fast charged? }\end{array}$ & No \\
\hline Have you had to replace any NEV battery packs? & No \\
\hline \multicolumn{2}{|l|}{$\begin{array}{l}\text { If yes, what was the average pack cost or were they under } \\
\text { warranty? }\end{array}$} \\
\hline $\begin{array}{l}\text { If yes, what were the average miles on the replaced battery } \\
\operatorname{pack}(\mathrm{s}) ?\end{array}$ & \\
\hline \multicolumn{2}{|l|}{ Please provide any additional comments you have: } \\
\hline
\end{tabular}




\begin{tabular}{|c|c|}
\hline \multicolumn{2}{|c|}{ Agency/Department/Company: East Campus Commercial Organization } \\
\hline \multicolumn{2}{|l|}{ Location: San Jose, CA } \\
\hline $\begin{array}{l}\text { How may 4-wheeled passenger/pickup/utility vehicles are in } \\
\text { your fleet (including NEVs)? }\end{array}$ & 2 \\
\hline How many NEVs are in your fleet? & 2 GEMs \\
\hline What are the NEVs generally used for? & Allow people to try them out \\
\hline How long have you had NEVs in your fleet? & Beginning July 2000 \\
\hline Do you have any more NEVs on order (if yes, please specify)? & No \\
\hline Have you had any problems with the NEVs? & No \\
\hline $\begin{array}{l}\text { How many miles are your NEVs driven on average } \\
\text { Per NEV? } \\
\text { Per NEV Fleet? }\end{array}$ & 1,000 and 1,100 at end of Feb \\
\hline How many NEVs were replacement vehicles? & 0 \\
\hline \multicolumn{2}{|l|}{$\begin{array}{l}\text { If replacement vehicles, list how many and what types of } \\
\text { vehicles the NEVs replaced: }\end{array}$} \\
\hline $\begin{array}{l}\text { Are your NEVs used on public roads, private roads/base, or } \\
\text { both? }\end{array}$ & Public roads \\
\hline $\begin{array}{l}\text { Are there any additional features you would like your NEVs to } \\
\text { have: }\end{array}$ & Solid doors, windows that roll down \\
\hline Are you using 110 or $220 \mathrm{~V}$ charging? & 110 \\
\hline $\begin{array}{l}\text { Are you using fast charging for your NEVs? } \\
\text { If yes, how many NEVs are being fast charged? }\end{array}$ & No \\
\hline Have you had to replace any NEV battery packs? & No \\
\hline \multicolumn{2}{|l|}{$\begin{array}{l}\text { If yes, what was the average pack cost or were they under } \\
\text { warranty? }\end{array}$} \\
\hline \multicolumn{2}{|l|}{$\begin{array}{l}\text { If yes, what were the average miles on the replaced battery } \\
\operatorname{pack}(\mathrm{s}) \text { ? }\end{array}$} \\
\hline \multicolumn{2}{|l|}{ Please provide any additional comments you have: } \\
\hline Non-profit organization used for neighborhoods. & \\
\hline
\end{tabular}




\begin{tabular}{|c|c|}
\hline \multicolumn{2}{|l|}{ Agency/Department/Company: Key West Cruisers } \\
\hline \multicolumn{2}{|l|}{ Location: Keywest, FL } \\
\hline \multicolumn{2}{|l|}{$\begin{array}{l}\text { How may 4-wheeled passenger/pickup/utility vehicles are in } \\
\text { your fleet (including NEVs)? }\end{array}$} \\
\hline How many NEVs are in your fleet? & 78 GEMs, mostly 4 seaters \\
\hline What are the NEVs generally used for? & Rental vehicles \\
\hline How long have you had NEVs in your fleet? & 2 years \\
\hline Do you have any more NEVs on order (if yes, please specify)? & No, possibly in the future \\
\hline Have you had any problems with the NEVs? & Chargers, front suspension \\
\hline $\begin{array}{l}\text { How many miles are your NEVs driven on average } \\
\text { Per NEV? } \\
\text { Per NEV Fleet? }\end{array}$ & 15 miles/day \\
\hline How many NEVs were replacement vehicles? & 0 \\
\hline \multicolumn{2}{|l|}{$\begin{array}{l}\text { If replacement vehicles, list how many and what types of } \\
\text { vehicles the NEVs replaced: }\end{array}$} \\
\hline $\begin{array}{l}\text { Are your NEVs used on public roads, private roads/base, or } \\
\text { both? }\end{array}$ & Public \\
\hline $\begin{array}{l}\text { Are there any additional features you would like your NEVs to } \\
\text { have: }\end{array}$ & No \\
\hline Are you using 110 or $220 \mathrm{~V}$ charging? & 110 \\
\hline $\begin{array}{l}\text { Are you using fast charging for your NEVs? } \\
\text { If yes, how many NEVs are being fast charged? }\end{array}$ & No \\
\hline Have you had to replace any NEV battery packs? & No \\
\hline \multicolumn{2}{|l|}{$\begin{array}{l}\text { If yes, what was the average pack cost or were they under } \\
\text { warranty? }\end{array}$} \\
\hline $\begin{array}{l}\text { If yes, what were the average miles on the replaced battery } \\
\operatorname{pack}(\mathrm{s}) ?\end{array}$ & \\
\hline \multicolumn{2}{|l|}{ Please provide any additional comments you have: } \\
\hline
\end{tabular}




\begin{tabular}{|c|c|}
\hline Agency/Department/Company: Luke Air Force Base - DOD & \\
\hline Location: Phoenix, AZ & \\
\hline $\begin{array}{l}\text { How may 4-wheeled passenger/pickup/utility vehicles are in } \\
\text { your fleet (including NEVs)? }\end{array}$ & 831 \\
\hline How many NEVs are in your fleet? & $\begin{array}{l}69 \text { GEMs, } 13 \text { Bombardiers, Totaling } \\
82\end{array}$ \\
\hline What are the NEVs generally used for? & \\
\hline How long have you had NEVs in your fleet? & Majority 2000, oldest 98 \\
\hline Do you have any more NEVs on order (if yes, please specify)? & Don't know, hopefully \\
\hline Have you had any problems with the NEVs? & $\begin{array}{l}\text { Some controller boxes, } 1-2 \\
\text { transmissions }\end{array}$ \\
\hline $\begin{array}{l}\text { How many miles are your NEVs driven on average } \\
\text { Per NEV? } \\
\text { Per NEV Fleet? }\end{array}$ & \\
\hline How many NEVs were replacement vehicles? & 7 \\
\hline $\begin{array}{l}\text { If replacement vehicles, list how many and what types of } \\
\text { vehicles the NEVs replaced: }\end{array}$ & Golf carts \\
\hline $\begin{array}{l}\text { Are your NEVs used on public roads, private roads/base, or } \\
\text { both? }\end{array}$ & Base only \\
\hline $\begin{array}{l}\text { Are there any additional features you would like your NEVs to } \\
\text { have: }\end{array}$ & $\begin{array}{l}\text { Permanent doors, hooks for towing, } \\
\text { bins }\end{array}$ \\
\hline Are you using 110 or $220 \mathrm{~V}$ charging? & 110 \\
\hline $\begin{array}{l}\text { Are you using fast charging for your NEVs? } \\
\text { If yes, how many NEVs are being fast charged? }\end{array}$ & No \\
\hline Have you had to replace any NEV battery packs? & No \\
\hline $\begin{array}{l}\text { If yes, what was the average pack cost or were they under } \\
\text { warranty? }\end{array}$ & \\
\hline $\begin{array}{l}\text { If yes, what were the average miles on the replaced battery } \\
\text { pack(s)? }\end{array}$ & \\
\hline Please provide any additional comments you have: & \\
\hline
\end{tabular}




\begin{tabular}{|c|c|}
\hline \multicolumn{2}{|l|}{ Agency/Department/Company: Marion County Sheriff's Office } \\
\hline \multicolumn{2}{|l|}{ Location: Ocala, FL } \\
\hline $\begin{array}{l}\text { How may } 4 \text {-wheeled passenger/pickup/utility vehicles are in } \\
\text { your fleet (including NEVs)? }\end{array}$ & 509 \\
\hline How many NEVs are in your fleet? & 12 Bombardier \\
\hline What are the NEVs generally used for? & $\begin{array}{l}9-\text { school campus patrol, } 3 \text { - patrol } \\
\text { tight areas }\end{array}$ \\
\hline How long have you had NEVs in your fleet? & 3 years \\
\hline Do you have any more NEVs on order (if yes, please specify)? & No, but will in the future \\
\hline Have you had any problems with the NEVs? & $\begin{array}{l}4 \text { controller failures, } 5 \text { malfunction } \\
\text { switches }\end{array}$ \\
\hline $\begin{array}{l}\text { How many miles are your NEVs driven on average } \\
\text { Per NEV? } \\
\text { Per NEV Fleet? }\end{array}$ & $\begin{array}{l}\text { Schools: } 15-20 \text { miles/day, other: } 50 \\
\text { miles/day }\end{array}$ \\
\hline How many NEVs were replacement vehicles? & 0 \\
\hline \multicolumn{2}{|l|}{$\begin{array}{l}\text { If replacement vehicles, list how many and what types of } \\
\text { vehicles the NEVs replaced: }\end{array}$} \\
\hline $\begin{array}{l}\text { Are your NEVs used on public roads, private roads/base, or } \\
\text { both? }\end{array}$ & Public \\
\hline $\begin{array}{l}\text { Are there any additional features you would like your NEVs to } \\
\text { have: }\end{array}$ & $\begin{array}{l}\text { Higher speeds ( } 35 \mathrm{mph}) \text {, longer } \\
\text { range, faster charging }\end{array}$ \\
\hline Are you using 110 or $220 \mathrm{~V}$ charging? & 110 \\
\hline $\begin{array}{l}\text { Are you using fast charging for your NEVs? } \\
\text { If yes, how many NEVs are being fast charged? }\end{array}$ & No \\
\hline Have you had to replace any NEV battery packs? & 5 \\
\hline $\begin{array}{l}\text { If yes, what was the average pack cost or were they under } \\
\text { warranty? }\end{array}$ & $\$ 600$ \\
\hline $\begin{array}{l}\text { If yes, what were the average miles on the replaced battery } \\
\operatorname{pack}(\mathrm{s}) \text { ? }\end{array}$ & $2 \frac{1}{2}-3$ years \\
\hline \multicolumn{2}{|l|}{ Please provide any additional comments you have: } \\
\hline They need to get them around. & \\
\hline
\end{tabular}




\begin{tabular}{|c|c|}
\hline Agency/Department/Company: Melbourne Police Department & \\
\hline Location: Melbourne, FL & \\
\hline $\begin{array}{l}\text { How may 4-wheeled passenger/pickup/utility vehicles are in } \\
\text { your fleet (including NEVs)? }\end{array}$ & \\
\hline How many NEVs are in your fleet? & 2 Bombardier \\
\hline What are the NEVs generally used for? & Neighborhood patrol \\
\hline How long have you had NEVs in your fleet? & 4 years \\
\hline Do you have any more NEVs on order (if yes, please specify)? & No, but will in the future \\
\hline Have you had any problems with the NEVs? & No \\
\hline $\begin{array}{l}\text { How many miles are your NEVs driven on average } \\
\text { Per NEV? } \\
\text { Per NEV Fleet? }\end{array}$ & 8 miles/week \\
\hline How many NEVs were replacement vehicles? & 0 \\
\hline $\begin{array}{l}\text { If replacement vehicles, list how many and what types of } \\
\text { vehicles the NEVs replaced: }\end{array}$ & \\
\hline $\begin{array}{l}\text { Are your NEVs used on public roads, private roads/base, or } \\
\text { both? }\end{array}$ & Public \\
\hline $\begin{array}{l}\text { Are there any additional features you would like your NEVs to } \\
\text { have: }\end{array}$ & Permanent doors \\
\hline Are you using 110 or $220 \mathrm{~V}$ charging? & 110 \\
\hline $\begin{array}{l}\text { Are you using fast charging for your NEVs? } \\
\text { If yes, how many NEVs are being fast charged? }\end{array}$ & No \\
\hline Have you had to replace any NEV battery packs? & Yes, 2 \\
\hline $\begin{array}{l}\text { If yes, what was the average pack cost or were they under } \\
\text { warranty? }\end{array}$ & Yes \\
\hline $\begin{array}{l}\text { If yes, what were the average miles on the replaced battery } \\
\operatorname{pack}(\mathrm{s}) \text { ? }\end{array}$ & $21 / 2-3$ years \\
\hline Please provide any additional comments you have: & \\
\hline
\end{tabular}




\begin{tabular}{|c|c|}
\hline \multicolumn{2}{|l|}{ Agency/Department/Company: Nauman Hobbs Material Handling } \\
\hline \multicolumn{2}{|l|}{ Location: Phoenix, AZ } \\
\hline $\begin{array}{l}\text { How may 4-wheeled passenger/pickup/utility vehicles are in } \\
\text { your fleet (including NEVs)? }\end{array}$ & 180 \\
\hline How many NEVs are in your fleet? & 32 GEMs \\
\hline What are the NEVs generally used for? & Rental \\
\hline How long have you had NEVs in your fleet? & $1 \frac{1}{2}$ years \\
\hline Do you have any more NEVs on order (if yes, please specify)? & No \\
\hline Have you had any problems with the NEVs? & $\begin{array}{l}\text { Battery chargers, batteries, axles, } \\
\text { front steering system }\end{array}$ \\
\hline \multicolumn{2}{|l|}{ How many miles are your NEVs driven on average } \\
\hline \multicolumn{2}{|l|}{ Per NEV? } \\
\hline \multicolumn{2}{|l|}{ Per NEV Fleet? } \\
\hline How many NEVs were replacement vehicles? & 32 \\
\hline $\begin{array}{l}\text { If replacement vehicles, list how many and what types of } \\
\text { vehicles the NEVs replaced: }\end{array}$ & Gas golf and industrial carts \\
\hline $\begin{array}{l}\text { Are your NEVs used on public roads, private roads/base, or } \\
\text { both? }\end{array}$ & Both \\
\hline $\begin{array}{l}\text { Are there any additional features you would like your NEVs to } \\
\text { have: }\end{array}$ & Carry more passengers \\
\hline Are you using 110 or $220 \mathrm{~V}$ charging? & 110 \\
\hline $\begin{array}{l}\text { Are you using fast charging for your NEVs? } \\
\text { If yes, how many NEVs are being fast charged? }\end{array}$ & No \\
\hline Have you had to replace any NEV battery packs? & Yes, 6 \\
\hline $\begin{array}{l}\text { If yes, what was the average pack cost or were they under } \\
\text { warranty? }\end{array}$ & Under warranty \\
\hline $\begin{array}{l}\text { If yes, what were the average miles on the replaced battery } \\
\operatorname{pack}(s) \text { ? }\end{array}$ & Replaced within the first year \\
\hline \multicolumn{2}{|l|}{ Please provide any additional comments you have: } \\
\hline \multicolumn{2}{|c|}{ We have found that the 6 -volt battery packs hold up better than the 8 and 12 -volt battery packs. } \\
\hline
\end{tabular}




\begin{tabular}{|c|c|}
\hline Agency/Department/Company: Southwest Airlines & \\
\hline Location: Phoenix, AZ & \\
\hline $\begin{array}{l}\text { How may 4-wheeled passenger/pickup/utility vehicles are in } \\
\text { your fleet (including NEVs)? }\end{array}$ & $?$ \\
\hline How many NEVs are in your fleet? & 12 GEMs \\
\hline What are the NEVs generally used for? & Ground support \\
\hline How long have you had NEVs in your fleet? & June 00 \\
\hline Do you have any more NEVs on order (if yes, please specify)? & 2 \\
\hline Have you had any problems with the NEVs? & $\begin{array}{l}\text { Problem with water level in batteries, } \\
\text { replaced with gel cells }\end{array}$ \\
\hline $\begin{array}{l}\text { How many miles are your NEVs driven on average } \\
\text { Per NEV? } \\
\text { Per NEV Fleet? }\end{array}$ & 15 miles/day, 7 days/week per vehicle \\
\hline How many NEVs were replacement vehicles? & 6 \\
\hline $\begin{array}{l}\text { If replacement vehicles, list how many and what types of } \\
\text { vehicles the NEVs replaced: }\end{array}$ & 5 gasoline golf carts, 1 diesel golf cart \\
\hline $\begin{array}{l}\text { Are your NEVs used on public roads, private roads/base, or } \\
\text { both? }\end{array}$ & Only on Airport service roads \\
\hline $\begin{array}{l}\text { Are there any additional features you would like your NEVs to } \\
\text { have: }\end{array}$ & Canvas doors \\
\hline Are you using 110 or $220 \mathrm{~V}$ charging? & 110 \\
\hline $\begin{array}{l}\text { Are you using fast charging for your NEVs? } \\
\text { If yes, how many NEVs are being fast charged? }\end{array}$ & No \\
\hline Have you had to replace any NEV battery packs? & 1 set \\
\hline $\begin{array}{l}\text { If yes, what was the average pack cost or were they under } \\
\text { warranty? }\end{array}$ & $\$ 912$ \\
\hline $\begin{array}{l}\text { If yes, what were the average miles on the replaced battery } \\
\operatorname{pack}(\mathrm{s}) \text { ? }\end{array}$ & \\
\hline Please provide any additional comments you have: & \\
\hline
\end{tabular}




\begin{tabular}{|c|c|}
\hline \multicolumn{2}{|l|}{ Agency/Department/Company: Yuma Marine Base - DOD } \\
\hline \multicolumn{2}{|l|}{ Location: Yuma, AZ } \\
\hline $\begin{array}{l}\text { How may 4-wheeled passenger/pickup/utility vehicles are in } \\
\text { your fleet (including NEVs)? }\end{array}$ & 475 \\
\hline How many NEVs are in your fleet? & 35 GEMs \\
\hline What are the NEVs generally used for? & $80 \%$ Admin, 20\% Delivery Capacity \\
\hline How long have you had NEVs in your fleet? & Mid October 00 \\
\hline Do you have any more NEVs on order (if yes, please specify)? & No \\
\hline Have you had any problems with the NEVs? & 1 Charging system \\
\hline $\begin{array}{l}\text { How many miles are your NEVs driven on average } \\
\text { Per NEV? } \\
\text { Per NEV Fleet? }\end{array}$ & 70 miles/month/vehicle \\
\hline How many NEVs were replacement vehicles? & 35 \\
\hline $\begin{array}{l}\text { If replacement vehicles, list how many and what types of } \\
\text { vehicles the NEVs replaced: }\end{array}$ & Gasoline Scooters \\
\hline $\begin{array}{l}\text { Are your NEVs used on public roads, private roads/base, or } \\
\text { both? }\end{array}$ & Base only \\
\hline $\begin{array}{l}\text { Are there any additional features you would like your NEVs to } \\
\text { have: }\end{array}$ & \\
\hline Are you using 110 or $220 \mathrm{~V}$ charging? & 110 \\
\hline $\begin{array}{l}\text { Are you using fast charging for your NEVs? } \\
\text { If yes, how many NEVs are being fast charged? }\end{array}$ & No \\
\hline Have you had to replace any NEV battery packs? & No \\
\hline $\begin{array}{l}\text { If yes, what was the average pack cost or were they under } \\
\text { warranty? }\end{array}$ & \\
\hline $\begin{array}{l}\text { If yes, what were the average miles on the replaced battery } \\
\operatorname{pack}(\mathrm{s}) \text { ? }\end{array}$ & \\
\hline \multicolumn{2}{|c|}{$\begin{array}{l}\text { Please provide any additional comments you have: } \\
\text { The vehicles are very capable - tough to make paradigm shift by drivers. Slowly getting it in Yuma, } 1 \\
\text { negative to } 10 \text { positive. Very capable vehicles, just need to get customer buy in. Everything is made of } \\
\text { plastic and deteriorates quickly. }\end{array}$} \\
\hline
\end{tabular}




\begin{tabular}{|c|c|}
\hline \multicolumn{2}{|l|}{ Agency/Department/Company: Zapworld.com } \\
\hline \multicolumn{2}{|l|}{ Location: Sebastopol, CA } \\
\hline $\begin{array}{l}\text { How may 4-wheeled passenger/pickup/utility vehicles are in } \\
\text { your fleet (including NEVs)? }\end{array}$ & 9 \\
\hline How many NEVs are in your fleet? & 3 GEMs \\
\hline What are the NEVs generally used for? & Transportation, maintenance \\
\hline How long have you had NEVs in your fleet? & Approx. 1 year \\
\hline Do you have any more NEVs on order (if yes, please specify)? & No \\
\hline Have you had any problems with the NEVs? & No \\
\hline $\begin{array}{l}\text { How many miles are your NEVs driven on average } \\
\text { Per NEV? } \\
\text { Per NEV Fleet? }\end{array}$ & 3 miles/day/NEV \\
\hline How many NEVs were replacement vehicles? & 0 \\
\hline \multicolumn{2}{|l|}{$\begin{array}{l}\text { If replacement vehicles, list how many and what types of } \\
\text { vehicles the NEVs replaced: }\end{array}$} \\
\hline $\begin{array}{l}\text { Are your NEVs used on public roads, private roads/base, or } \\
\text { both? }\end{array}$ & Public roads \\
\hline $\begin{array}{l}\text { Are there any additional features you would like your NEVs to } \\
\text { have: }\end{array}$ & Permanent doors \\
\hline Are you using 110 or $220 \mathrm{~V}$ charging? & 110 \\
\hline $\begin{array}{l}\text { Are you using fast charging for your NEVs? } \\
\text { If yes, how many NEVs are being fast charged? }\end{array}$ & No \\
\hline Have you had to replace any NEV battery packs? & No \\
\hline \multicolumn{2}{|l|}{$\begin{array}{l}\text { If yes, what was the average pack cost or were they under } \\
\text { warranty? }\end{array}$} \\
\hline \multicolumn{2}{|l|}{$\begin{array}{l}\text { If yes, what were the average miles on the replaced battery } \\
\operatorname{pack}(\mathrm{s}) \text { ? }\end{array}$} \\
\hline \multicolumn{2}{|l|}{ Please provide any additional comments you have: } \\
\hline \multicolumn{2}{|c|}{ Great. They work well, very happy to use them. All you need is the right tool for the right job. } \\
\hline
\end{tabular}

